\section{A preliminary survey on the avian community of Dalma Wildlife Sanctuary, Jharkhand, India}

\section{Sushant Kumar Verma}

At \& P.O.- Harharguttu, Near TRF Colony, Jamshedpur, Jharkhand 831002, India

Email: vermasushant2008@gmail.com

The importance of local landscapes for avian conservation can only be understood by knowing the structure of the bird community of that region (Kattan \& Franco 2004). Bird diversity of both temperate and tropical forests has been studied by many workers from time to time (MacArthur \& MacArthur 1961; Terborgh et al. 1990; Thiollay 1994; Robinson et al. 2000; Latta et al. 2003; Blake 2007). Valuable information on factors influencing population dynamics, interactions, community structure, and conservation can be gathered by monitoring seasonal changes of avifauna (Ornelas et al. 1993). Seasonal fluctuations in abundance and number of species have been studied in several temperate (Anderson et al. 1981; Best 1981), as well as in tropical avian communities (Karr 1981; Blake 1992; Blake \& Loiselle 2000).

Date of publication (online): 26 May 2011

Date of publication (print): 26 May 2011

ISSN 0974-7907 (online) | 0974-7893 (print)

Editor: Nishith Dharaiya

\section{Manuscript details:}

Ms \# 02181

Received 21 April 2009

Final received 05 April 2011

Finally accepted 26 April 2011

Citation: Verma, S.K. (2011). A preliminary survey on the avian community of Dalma Wildlife Sanctuary, Jharkhand, India. Journal of Threatened Taxa 3(5): 1764-1770.

Copyright: @ Sushant Kumar Verma 2011. Creative Commons Attribution 3.0 Unported License. JoTT allows unrestricted use of this article in any medium for non-profit purposes, reproduction and distribution by providing adequate credit to the authors and the source of publication.

Acknowledgements: I am grateful to Dr. A. Alim, Head of the Department of Zoology, Jamshedpur Co-operative College, Jamshedpur, for his valuable suggestions. I also wish to thank Miss Ghazala Sabih (MCA Project Trainee, TISCO) and Master Aditya Karan Verma for their constructive criticism and untiring help throughout the study period. I am also thankful to the local people residing near Dalma Wildlife Sanctuary for availing themselves to me. They have opened their hearts and their doors, supplying me with resources which helped me a lot in data collection.

OPEN ACCESS | FREE DOWNLOAD
Very few studies (Ball 1874; Lopez \& Mundkar 1997; Gupta 2004) have been made on the species composition of birds in different parts of Jharkhand (India) and no attempt has been made to study the avifauna of Dalma Wildlife Sanctuary. The present study investigates the bird community of this sanctuary, their seasonal variations and also highlights conservation challenges. A comprehensive checklist of birds along with their status is also presented in this document.

\section{Study Area}

The Dalma Wildlife Sanctuary which extends over $193 \mathrm{~km}^{2}$ in the thick forest of the Dalma Mountain range is located $10 \mathrm{~km}$ from Jamshedpur in Jharkhand (India). This wildlife sanctuary is blessed with a nearby flowing river called Subarnarekha. Dimna Lake, which is located down the Dalma Hills, provides an excellent habitat for resident aquatic birds. Several migratory birds visit this lake every year during winter. An image of the study area was downloaded from the internet with the help of Google earth software (Image $1)$.

Climatic conditions in Dalma are typical of Indian sal forest and its natural vegetation comprises a combination of Sal forest and tropical dry deciduous types. The hottest months are May and June in which the temperature may rise up to $44^{\circ} \mathrm{C}$. The period from November to February is comparatively cool with an average temperature of $10^{\circ} \mathrm{C}$. The maximum rainfall is received during the months of July and August from the south west monsoon. The luxuriant forest of this sanctuary offers excellent habitat for its inhabitants. These forests contain a large number of wild birds that are ecologically specialized and extremely sensitive to habitat loss. Deforestation, pollution, and the introduction of cattle are seriously threatening these forests.

\section{Methods}

Bird Sampling: The bird community of Dalma Wildlife Sanctuary, Jharkhand was studied during September 2006 to November 2008. A combination of variable radius point count method (Bibby et al. 2000) and transect method (Emlen 1971) was used for the sampling of birds. Four transects $(2 \mathrm{~km}$ length and 


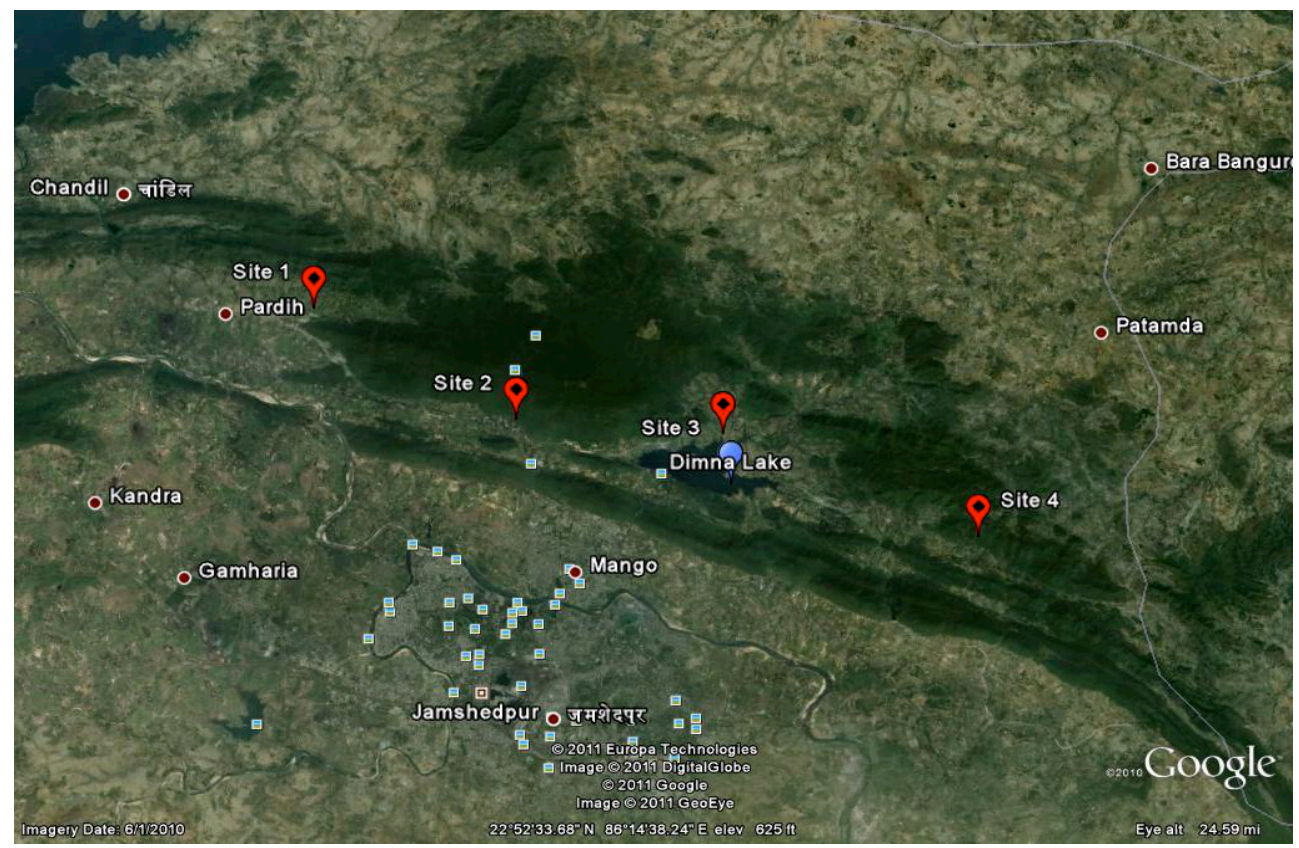

Image 1. Dalma Wildlife Sanctuary downloded from Google Earth showing the four different sampling sites where transects were laid.

$100 \mathrm{~m}$ width) were laid within the sanctuary at different sites (Table 1). Five permanent sampling points were established in each transect and a distance of $100 \mathrm{~m}$ was maintained between them. Seasonal variation was determined by dividing each year into four seasons. These seasons were (1) spring-February and March, (2) summer-April to June, (3) rainy season (monsoon) - July to September and (4) winter (post monsoon) - October to January. For each year a data matrix was constructed which recorded the species and their abundance in each season. Sampling was conducted, mostly in the morning $(0700-0900 \mathrm{hr})$ and in the evening (1600-1900 hr). Each bird seen was recorded at every point distributed along each transect. Each point was sampled three times a season making a total of 240 point counts.

Data analysis: The cumulative number of species observed in each site was considered as the species richness for that site. Based on the present investigations a bird list was compiled (Table 5). Shannon-Wiener diversity index $\left(H=-\Sigma p^{i} \ln p^{i}\right)$ was calculated for each site. Seasonal variation in the abundance of birds was also calculated using the Shannon-Weiner formula. Similarity between sites was determined by Sorensen's index of similarity as given below:

$\mathrm{IS}=2 \mathrm{j} /(\mathrm{a}+\mathrm{b})$
Table 1. Details of transects laid in the Dalma Wildlife Sanctuary, Jharkhand, India for bird sampling.

\begin{tabular}{|c|c|c|}
\hline \multirow{2}{*}{$\begin{array}{c}\text { Transects } \\
\text { (Sites) }\end{array}$} & \multicolumn{2}{|c|}{ Geographical parameters } \\
\cline { 2 - 3 } & Latitude & Longitude \\
\hline 1 & $22^{0} 54^{\prime} 54.96 ” \mathrm{~N}$ & $86^{\circ} 07^{\prime} 31.93^{\prime \prime} \mathrm{E}$ \\
\hline 2 & $22^{0} 52^{\prime} 42.28^{\prime \prime} \mathrm{N}$ & $86^{0} 11^{\prime} 44.86^{\prime \prime} \mathrm{E}$ \\
\hline 3 & $22^{\circ} 52^{\prime} 25.39^{\prime \prime} \mathrm{N}$ & $86^{0} 16^{\prime} 02.44^{\prime \prime} \mathrm{E}$ \\
\hline 4 & $22^{0} 50^{\prime} 23.43^{\prime \prime} \mathrm{N}$ & $86^{0} 21^{\prime} 19.61^{\prime \prime} \mathrm{E}$ \\
\hline
\end{tabular}

Table 2. Sorensen's index representing the similarity values between study sites in Dalma Wildlife Sanctuary

\begin{tabular}{|l|c|c|c|}
\hline & Site 2 & Site 3 & Site 4 \\
\hline Site 1 & 0.56 & 0.59 & 0.64 \\
\hline Site 2 & & 0.61 & 0.55 \\
\hline Site 3 & & & 0.61 \\
\hline
\end{tabular}

where $\mathrm{j}=$ number of species common to both sites $\mathrm{a}=$ number of species in site $\mathrm{A}$

$\mathrm{b}=$ number of species in site B. (Table 2)

One-way analysis of variance (ANOVA) was performed to test for differences between sites in terms of species richness and diversity values.

Bird species were ranked into following abundance categories (Ramírez-Albores \& Ramírez 2002): abundant (total of 40 or more individuals recorded 
daily), common (17 to 39 individuals recorded daily), scarce (11 to 16 individuals recorded), irregular (five to 10 individuals recorded) and rare (one to four individuals recorded). Species were identified directly in the field and where identification could not be done, photographs were taken. They were identified with the help of field guides (Grimmett et al. 1999; Kazmierczak \& Singh 2001; Ali 2001).

Taxonomy adopted here is after Inskipp et al. (1996).

\section{Results}

A total of 71 species grouped into 36 families were recorded from the Dalma Wildlife Sanctuary during the study period (Table 5). The Sturnidae family shows the highest species richness within the sanctuary (five species), followed by Muscicapidae, Motacicillidae, Columbidae, Ardeidae, Anatidae (four species of each) (Table 5). The species richness of selected sites varied between 39 to 51 (Table 3), while overall diversity values ranged from 2.87 to 3.33 (Table 4). Of the species recorded in this study, 51 species were resident and the remaining species were recorded as migratory (Table 5). On the basis of relative abundance four species can be considered as rare, seven as irregular, 17 as scarce, 25 as common and 18 as abundant (Table 5, Fig. 1). A distinct seasonal variation in avian species richness was observed with a peak during the monsoons representing 43 species. However, species richness and the diversity values for the sites were

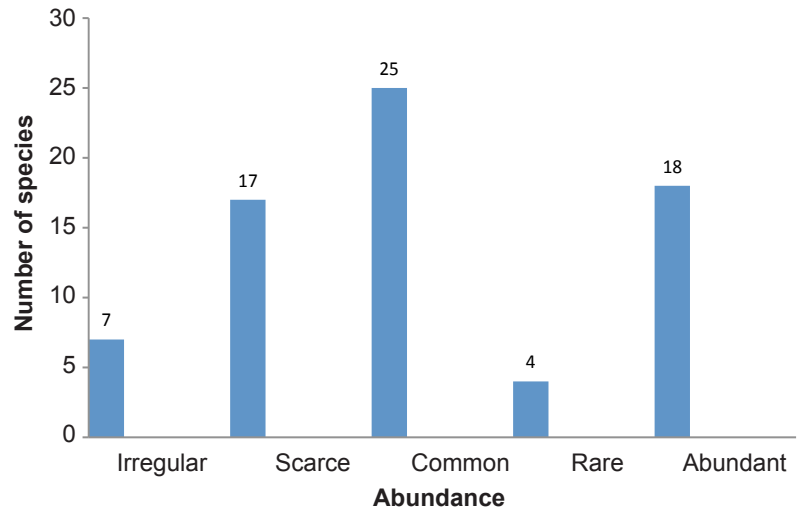

Figure 1. Relative abundance of bird species in Dalma Wildlife Sanctuary

seasonally almost similar (ANOVA, $\mathrm{p}>0.05$ ).

\section{Discussion}

The two-year study observed 71 species from the Dalma Wildlife Sanctuary, which shows that this sanctuary supports a high diversity of birds. Most of the observed species are breeding residents mainly due to occurrence of various types of microhabitat within the sanctuary, nearby river and a large lake. Due to the abundance of endemic species this sanctuary is very important for bird conservation in this part of the world.

Seasonal changes in species richness were observed which is mainly due to changes in weather conditions or fluctuations in food productivity and habitat quality (Loiselle \& Blake 1991; Norris \& Marra 2007). Species

Table 3. Bird species richness for study sites in Dalma Wildlife Sanctuary, Jharkhand, India

\begin{tabular}{|c|c|c|c|c|c|}
\hline $\begin{array}{c}\text { Transects } \\
\text { (Sites) }\end{array}$ & $\begin{array}{c}\text { Total } \\
\text { Richness }\end{array}$ & $\begin{array}{c}\text { Richness } \\
\text { (Spring) }\end{array}$ & $\begin{array}{c}\text { Richness } \\
\text { (Summer) }\end{array}$ & $\begin{array}{c}\text { Richness } \\
\text { (Rainy season) }\end{array}$ & $\begin{array}{c}\text { Richness } \\
\text { (Winter) }\end{array}$ \\
\hline 1 & 42 & 32 & 27 & 39 & 31 \\
\hline 2 & 51 & 36 & 31 & 43 & 33 \\
\hline 3 & 44 & 29 & 27 & 34 & 28 \\
\hline 4 & 39 & 31 & 30 & 37 & 30 \\
\hline
\end{tabular}

Table 4. Bird diversity values for study sites in Dalma Wildlife Sanctuary, Jharkhand, India

\begin{tabular}{|c|c|c|c|c|c|}
\hline $\begin{array}{c}\text { Transects } \\
\text { (Sites) }\end{array}$ & $\begin{array}{c}\text { Total Diversity } \\
\text { Value }\end{array}$ & $\begin{array}{c}\text { Diversity Value } \\
\text { (Spring) }\end{array}$ & $\begin{array}{c}\text { Diversity Value } \\
\text { (Summer) }\end{array}$ & $\begin{array}{c}\text { Diversity Value } \\
\text { (Rainy Season) }\end{array}$ & $\begin{array}{c}\text { Diversity Value } \\
\text { (Winter) }\end{array}$ \\
\hline 1 & 3.21 & 3.09 & 2.84 & 3.11 & 2.98 \\
\hline 2 & 3.33 & 3.17 & 2.99 & 3.03 & 2.83 \\
\hline 3 & 2.87 & 2.98 & 2.90 & 2.88 & 2.76 \\
\hline 4 & 3.01 & 3.00 & 2.85 & 2.68 & 2.89 \\
\hline
\end{tabular}


richness of birds in the sanctuary becomes maximum during the monsoon season due to greater availability of insects and favourable weather conditions.

Occurrence of almost same species richness and similar diversity values during a season for the different sites selected for the sampling indicates uniform distribution of birds throughout the sanctuary. The Dimna Lake which is a famous tourist spot is located in the vicinity of the Dalma Wildlife Sanctuary. Increasing tourist activity especially during the months of December and January is now becoming a serious threat to the birds of this sanctuary. Utilization of river beds for sand is imposing immense pressure on the birds that breed at the river beds. Cattle grazing and use of forest wood as a source of fuel by local people are also creating adverse conditions for the birds of the region.

Therefore various measures should be taken for the conservation of birds of the sanctuary. Cattle grazing should be allowed in a controlled manner. Alternative fuel sources should be made available to the local communities. Establishment of ecotourism committees with the help of local people and conducting awareness programs by the forest department on a regular basis would be an effective step in the avian diversity conservation of the Dalma Wildlife Sanctuary.

\section{REFERENCES}

Ali, S. (2001). The Book of Indian Birds-13th Edition. Bombay Natural History Society/Oxford University Press, 5-156

Anderson, B.W., R.D. Ohmart \& J. Rice (1981). Seasonal changes in detection of individual bird species, pp. 262-264. In: Ralph, C.J. \& J.M. Scott (eds.). Estimating the numbers of terrestrial birds. Studies in Avian Biology-6, 630pp.

Ball, V. (1874). Avifauna of Chotanagpur. Stray Feathers 2: $1-355$.

Best, L.B. (1981). Seasonal changes in detection of individual bird species, pp. 252-261. In: Ralph, C J. \& J.M. Scott (eds.). Estimating the numbers of terrestrial birds. Studies in Avian Biology-6, 630pp.

Bibby, C.J., N.D. Burgess, D.A. Hill \& S.H. Mustoe (2000). Bird Census Techniques-2nd Edition. Academic Press, London, pp.3-36.

Blake, J.G. (1992). Temporal variation in point counts of birds in a lowland wet forest in Costa Rica. Condor 94: 265275.

Blake, J.G. (2007). Neo-tropical forest bird communities: a comparison of species richness and composition at local and regional scales. Condor 109: 237-255.

Blake, J.G. \& B.A. Loiselle (2000). Diversity of birds along an elevational gradient in the Cordillera Central, Costa Rica. Auk 117: 663-686.

Emlen, J.T. (1971). Population densities of birds derived from transect counts. Auk 88: 323-342.

Grimmett R., C. Inskipp \& T. Inskipp (1999). Pocket Guide to the Birds of the Indian Subcontinent. Oxford University Press, 384pp.

Gupta, H.S. (2004). Waterbirds Diversity of Ranchi District. Zoos' Print Journal 19(9): 1630.

Inskipp, T., N. Lindsey \& W. Duckworth (1996). An Annotated Checklist of the Birds of the Oriental Region. Oriental Bird Club, Sandy, UK, 2-294.

Karr, J.R. (1981). Seasonal changes in detection of individual bird species, pp. 548-553. In: Ralph, C.J. \& J.M. Scott (eds.). Estimating the numbers of terrestrial birds. Studies in Avian Biology-6, 630pp.

Kattan, G.H. \& P. Franco (2004). Bird diversity along elevational gradients in the Andes of Colombia: area and mass effects. Global Ecology and Biogeography 13: 451458.

Kazmierczak K. \& R. Singh (2001). A Bird Watcher's Guide to India. Oxford University Press, 2-65pp.

Latta, S.C., C.C. Rimmer \& K.P. Mcfarland (2003). Winter bird communities in four habitats along an elevational gradient on Hispaniola. Condor 105: 179-197.

Loiselle, B.A. \& J.G. Blake (1991). Temporal variation in birds and fruits along an elevational gradient in Costa Rica. Ecology 72: 180-193.

Lopez, A. \& T. Mundkar (1997). The Asian Waterfall Census, 1994-1996.. Results of the coordinated waterbird census and an overview of the status of wetlands in Asia. Kuala Lumpur, Malaysia: Wetlands International, 4-35pp

MacArthur, R.H. \& J.W. MacArthur (1961). On bird species diversity. Journal of Ecology 42: 594-598.

Norris, D.R. \& P.P. Marra (2007). Seasonal interactions, habitat quality, and population dynamics in migratory birds. Condor 109: 535-547.

Ornelas, J.F., M.C. Arizmendi, L. Márquez-Valdelamar, L. Navarijo \& H. Berlanga (1993). Variability profiles for line transect bird censuses in a tropical dry forest in México. Condor 95: 422-441.

Ramírez-Albores, J.E. \& G. Ramírez (2002). Avifauna de la región oriente de la sierra de Huautla, Morelos, México. Anales del Instituto de Biologia, Universidad Nacional Autonoma de Mexico, Serie Zoologia 73: 91-111.

Robinson, W.D., J.D. Brawn \& S.K. Robinson (2000). Forest bird community structure in central Panama: influence of spatial scale and biogeography. Ecological Monographs 70: 209-235.

Terborgh, J., S.K. Robinson, T.A. Parker, C.A. Munn \& N. Pierpont (1990). Structure and organisation of an Amazonian forest bird community. Ecological Monographs 60: 213-238.

Thiollay, J.M. (1994). Structure, density and rarity in an 
Table 5. Checklist of birds recorded from Dalma Wildlife Sanctuary, Jharkhand, India

\begin{tabular}{|c|c|c|c|c|}
\hline & Common Name & Scientific Name & Status & Abundance \\
\hline & Accipitridae & & & \\
\hline \multirow[t]{2}{*}{1} & Black-shouldered Kite & Elanus caeruleus & $\mathrm{R}$ & 1 \\
\hline & Alaudidae & & & \\
\hline \multirow[t]{2}{*}{2} & Ashy-crowned Finch-lark & Eremopterix grisea & W & $S$ \\
\hline & Alcedinidae & & & \\
\hline 3 & Common Kingfisher & Alcedo atthis & $\mathrm{R}$ & $S$ \\
\hline \multirow[t]{2}{*}{4} & White-throated Kingfisher & Halcyon smyrnensis & $\mathrm{R}$ & $S$ \\
\hline & Anatidae & & & \\
\hline 5 & Northern Pintail & Anas acuta & W & S \\
\hline 6 & Gadwall & Anas strepera & W & $S$ \\
\hline 7 & Lesser Whistling-duck & Dendrocygna javanica & W & $\mathrm{S}$ \\
\hline \multirow[t]{2}{*}{8} & Comb Duck & Sarkidiornis melanotos & $\mathrm{R}$ & C \\
\hline & Ardeidae & & & \\
\hline 9 & Indian Pond-heron & Ardeola grayii & $\mathrm{R}$ & C \\
\hline 10 & Eastern Cattle Egret & Bubulcus coromandus & $\mathrm{R}$ & $\mathrm{C}$ \\
\hline 11 & Intermediate Egret & Mesophoyx intermedia & $\mathrm{R}$ & C \\
\hline \multirow[t]{2}{*}{12} & Black-crowned Night-heron & Nycticorax nycticorax & $\mathrm{R}$ & $\mathrm{S}$ \\
\hline & Burhinidae & & & \\
\hline \multirow[t]{2}{*}{13} & Indian Stone-curlew & Burhinus oedicnemus & $\mathrm{R}$ & $\mathrm{R}$ \\
\hline & Capitonidae & & & \\
\hline \multirow[t]{2}{*}{14} & Coppersmith Barbet & Megalaima haemacephala & $\mathrm{R}$ & $\mathrm{C}$ \\
\hline & Charadridae & & & \\
\hline 15 & Grey-headed Lapwing & Vanellus cinereus & W & $\mathrm{s}$ \\
\hline \multirow[t]{2}{*}{16} & Red-wattled Lapwing & Vanellus indicus & W & S \\
\hline & Cisticolidae & & & \\
\hline \multirow[t]{2}{*}{17} & Ashy Prinia & Prinia socialis & $\mathrm{R}$ & $\mathrm{C}$ \\
\hline & Columbidae & & & \\
\hline 18 & Rock Pigeon & Columba livia & $\mathrm{R}$ & C \\
\hline 19 & Spotted Dove & Streptopelia chinensis & $\mathrm{R}$ & $\mathrm{C}$ \\
\hline 20 & Eurasian Collared-dove & Streptopelia decaocto & $\mathrm{R}$ & C \\
\hline \multirow[t]{2}{*}{21} & Laughing Dove & Streptopelia senegalensis & $\mathrm{R}$ & C \\
\hline & Coraciidae & & & \\
\hline \multirow[t]{2}{*}{22} & Indian Roller & Coracias benghalensis & $\mathrm{R}$ & $\mathrm{C}$ \\
\hline & Corvidae & & & \\
\hline 23 & Indian Jungle Crow & Corvus macrorhynchos & $\mathrm{R}$ & $\mathrm{C}$ \\
\hline 24 & House Crow & Corvus splendens & $\mathrm{R}$ & A \\
\hline \multirow[t]{2}{*}{25} & Rufous Treepie & Dendrocitta vagabunda & $\mathrm{R}$ & S \\
\hline & Cuculidae & & & \\
\hline 26 & Greater Coucal & Centropus sinensis & $\mathrm{R}$ & $\mathrm{C}$ \\
\hline 27 & Asian Koel & Eudynamys scolopacea & $\mathrm{R}$ & C \\
\hline \multirow[t]{2}{*}{28} & Common Hawk-cuckoo & Hierococcyx varius & $\mathrm{R}$ & $\mathrm{S}$ \\
\hline & Daniidae & & & \\
\hline 29 & Brown Shrike & Lanius cristatus & $\mathrm{R}$ & C \\
\hline 30 & Black-headed Long-tailed Shrike & Lanius schach tricolor & $\mathrm{R}$ & S \\
\hline
\end{tabular}




\begin{tabular}{|c|c|c|c|c|}
\hline & Dicruridae & & & \\
\hline 31 & Ashy Drongo & Dicrurus leucophaeus & $\mathrm{R}$ & $\mathrm{S}$ \\
\hline \multirow[t]{2}{*}{32} & Black Drongo & Dicrurus macrocercus & $\mathrm{R}$ & C \\
\hline & Estrildidae & & & \\
\hline \multirow[t]{2}{*}{33} & Indian Silverbill & Lonchura malabarica & $\mathrm{R}$ & $\mathrm{S}$ \\
\hline & Accipitridae & & & \\
\hline \multirow[t]{2}{*}{34} & Black Kite & Milvus migrans & $\mathrm{R}$ & $\mathrm{C}$ \\
\hline & Hirundinidae & & & \\
\hline \multirow[t]{2}{*}{35} & Barn Swallow & Hirundo rustica & W & A \\
\hline & Jacanidae & & & \\
\hline 36 & Pheasant-tailed Jacana & Hydrophasianus chirurgus & W & $\mathrm{S}$ \\
\hline \multirow[t]{2}{*}{37} & Bronze-winged Jacana & Metopidius indicus & W & $\mathrm{S}$ \\
\hline & Meropidae & & & \\
\hline \multirow[t]{2}{*}{38} & Little Green Bee-eater & Merops orientalis & $\mathrm{R}$ & A \\
\hline & Motacicillidae & & & \\
\hline 39 & Paddyfield Pipit & Anthus rufuls & $\mathrm{R}$ & A \\
\hline 40 & White-browed Wagtail & Motacilla maderaspatensis & W & $\mathrm{S}$ \\
\hline 41 & White Wagtail & Motacilla. alba leucopsis & W & A \\
\hline \multirow[t]{2}{*}{42} & Western Yellow Wagtail & Motacilla.flava & W & A \\
\hline & Muscicapidae & & & \\
\hline 43 & Oriental Magpie-Robin & Copsychus saularis & $\mathrm{R}$ & A \\
\hline 44 & Red-breasted Flycatcher & Ficedula parva & S & $\mathrm{R}$ \\
\hline 45 & Indian Black Robin & Saxicoloides fulicata & $\mathrm{R}$ & I \\
\hline \multirow[t]{2}{*}{46} & Jungle Babbler & Turdoides striatus & $\mathrm{R}$ & A \\
\hline & Nectariniidae & & & \\
\hline \multirow[t]{2}{*}{47} & Purple Sunbird & Nectarinia asiatica & $\mathrm{R}$ & A \\
\hline & Oriolidae & & & \\
\hline \multirow[t]{2}{*}{48} & Indian Golden Oriole & Oriolus kundoo & $S$ & C \\
\hline & Phalacrocoracidae & & & \\
\hline \multirow[t]{2}{*}{49} & Little Cormorant & Phalacrocorax niger & S & $\mathrm{C}$ \\
\hline & Phasianidae & & & \\
\hline 50 & Grey Francolin & Francolinus pondicerianus & W & I \\
\hline \multirow[t]{2}{*}{51} & Indian Peafowl & Pavo cristatus & $\mathrm{R}$ & $\mathrm{C}$ \\
\hline & Picidae & & & \\
\hline \multirow[t]{2}{*}{52} & Woodpecker & Dendrocopos & $\mathrm{R}$ & $\mathrm{R}$ \\
\hline & Ploceidae & & & \\
\hline 53 & Scaly-breasted Munia & Lonchura punctulata & $\mathrm{R}$ & C \\
\hline 54 & House Sparrow & Passer domesticus & $\mathrm{R}$ & A \\
\hline \multirow[t]{2}{*}{55} & Indian Baya Weaver & Ploceus philippinus & $\mathrm{R}$ & A \\
\hline & Podicipitidae & & & \\
\hline \multirow[t]{2}{*}{56} & Little Grebe & Tachybaptus ruficollis & W & $\mathrm{C}$ \\
\hline & Psittacidae & & & \\
\hline 57 & Alexandrine Parakeet & Psittacula eupatria & $\mathrm{R}$ & A \\
\hline \multirow[t]{2}{*}{58} & Rose-ringed Parakeet & Psittacula krameri & $\mathrm{R}$ & A \\
\hline & Pycnonotidae & & & \\
\hline 59 & Red-vented Bulbul & Pycnonotus cafer & $\mathrm{R}$ & A \\
\hline 60 & Red-whiskered Bulbul & Pycnonotus jocosus & $\mathrm{R}$ & A \\
\hline
\end{tabular}




\begin{tabular}{|c|l|l|c|c|}
\hline & Rallidae & & & \\
\hline 61 & White-breasted Waterhen & Amaurornis phoenicurus & $\mathrm{R}$ & $\mathrm{C}$ \\
\hline 62 & Common Moorhen & Gallinula chloropus & $\mathrm{W}$ & $\mathrm{C}$ \\
\hline & Scolopacidae & & $\mathrm{S}$ & $\mathrm{I}$ \\
\hline 63 & Common Sandpiper & Actitis hypoleucos & $\mathrm{S}$ & $\mathrm{R}$ \\
\hline 64 & Green Sandpiper & Tringa ochropus & & $\mathrm{C}$ \\
\hline & Strigidae & & $\mathrm{R}$ & $\mathrm{A}$ \\
\hline 65 & Indian Eagle-owl & Bubo bengalensis & $\mathrm{R}$ & $\mathrm{A}$ \\
\hline & Sturnidae & & $\mathrm{R}$ & $\mathrm{A}$ \\
\hline 66 & Bank Myna & Acridotheres ginginianus & $\mathrm{R}$ & $\mathrm{I}$ \\
\hline 67 & Common Myna & Acridotheres tristis & $\mathrm{R}$ & $\mathrm{I}$ \\
\hline 68 & Asian Pied Starling & Sturnus contra & $\mathrm{R}$ & $\mathrm{R}$ \\
\hline 69 & Grey-headed Starling & Sturnus malabaricus - NE variant & & $\mathrm{I}$ \\
\hline 70 & Brahminy Starling & Sturnus pagodarum & & \\
\hline
\end{tabular}

Status: R - resident; W - winter visitor; T - transient; O - occasional; S - summer resident. Abundance: R - rare; I - irregular; S - scarce; C - common; A - abundant.

Amazonian rain forest bird community. Journal of Tropical Ecology 10: 449-481.

Wiens, J.A. (1989). Ecology of Bird Communities. Vols. I \& II.

Cambridge University Press, Cambridge, 2-90pp. 